\title{
A new bioactive ursane-type triterpenoid from Croton bonplandianum Bail
}

\author{
PRANAB GHOSH*, AMITAVA MANDAL and MOHAMMAD GOLAM RASUL \\ Department of Chemistry, University of North Bengal, Darjeeling, 734 013, India \\ e-mail:pizy12@yahoo.com
}

MS received 24 January 2012; revised 2 July 2012; accepted 8 October 2012

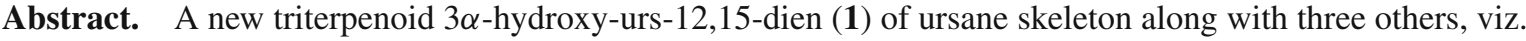
oleanolic acid (2) and ursolic acid (3) and $\beta$-sitosterol (4) were isolated from the root of Croton bonplandianum Bail. Their chemical structures were established on the basis of spectroscopic analysis (IR, 1D NMR, 2D NMR, Mass, etc.) and by chemical means. A probable biosynthetic pathway of compound $\mathbf{1}$ was also proposed. Preliminary investigation with the new compound showed potent activity against a series of fungal pathogens.
\end{abstract}

Keywords. Croton bonplandianum; $3 \alpha$-hydroxy-urs-12,15-dien; antifungal.

\section{Introduction}

Croton bonplandianum Bail belongs to the family of Euphorbiaceae, is native to southern Bolivia, Paraguay, southwestern Brazil and northern Argentina and was reported from India during late 1890 by Kaul. ${ }^{1}$ It now occurs widely along roadsides, railway abandoned field in wide open ravines, and paddy or sugarcane fields and on sandy or sandy clay soils. Due to the resemblance of the leaves and flower cymes to that of Tulsi, this plant is often called Ban Tulsi locally. C. bonplandianum was reported to have many medicinal uses including the repellent property against the insects, ${ }^{2-5}$ mosquito, A. aegypti. ${ }^{6}$ Local people in the remote area of West Bengal, India are using its root against snake bite and the leaf extract against high fever. In addition, the plant is used both as a fuel and as detergent. The methanol extract of $C$. bonplandianum has been found to exhibit antitumour properties using Agrobacterium tumefaciens and has larvicidal activities.

Phytochemically croton is rich in secondary metabolites including alkaloids and terpenoids. ${ }^{7,8}$ Diterpene resins found in many species of croton have been used experimentally in the studies of tumour initiation and conceivably prove to be useful in cancer therapy. ${ }^{9}$ Apart from the above limited reports, no systematic study has yet been initiated for the total phytochemical investigation of $C$. bonplandianum.

\section{Experimental}

\subsection{General experimental procedure}

Melting points were determined by open capillary method and were uncorrected. IR spectra were measured on Shimadzu 8300 FT-IR spectrophotometer. NMR spectra were recorded on Bruker-Avance 300 and $400 \mathrm{MHz}$ FT-NMR spectrometer. ESIMS was obtained on Applied Biosystem API 2000 and TOFMS were obtained on 4800 (ABSciex) MALDI-TOF/TOF Tandem Mass Spectrometer.

\subsection{Plant material}

Plants of $C$. bonplandianum used in this experiment were collected from North Bengal, India in May, 2008.

\subsection{Extraction and isolation}

The air dried roots of $C$. bonplandianum $(2 \mathrm{Kg})$ was chopped into small pieces and extracted with $\mathrm{MeOH}$ $(2 \mathrm{~L})$ in a soxhlet extractor for 7 days and $\mathrm{MeOH}$ was recovered in vacuo. The extracted mass ( $350 \mathrm{~g}$ ) was suspended in distilled water $(1 \mathrm{~L})$ and was partitioned successively between hexane $(300 \times 3)$, EtOAc $(300 \times 3)$ and $n-\mathrm{BuOH}(300 \times 3)$ to obtain four fractions (hexane phase, ethyl acetate phase, $n$-butanol phase and water phase). The ethyl acetate phase $(1.5 \mathrm{~g}$ ) was purified by repeated column chromatography (silica gel) using petroleum ether (PE) and PE:ethyl acetate of varying concentrations as eluent.

*For correspondence 


\subsection{Preparation of acetyl derivative of compound 1}

Compound 1 (100 mg, $0.23 \mathrm{mmol})$ in a $50 \mathrm{~mL}$ round bottom flask was warmed over a water bath with $10 \mathrm{~mL}$ of pyridine and $2 \mathrm{~mL}$ of acetic anhydride for $6 \mathrm{~h}$. The reaction mixture was then poured into $50 \mathrm{~mL}$ of ice cold water, worked up with ether, dried over anhydrous sodium sulphate. The crude product was then purified over a column of silica gel.

Purification of the gummy material, gave white crystalline monoacetate of $\mathrm{mp} 223-224{ }^{\circ} \mathrm{C}$. IR spectrum showed peaks at 2850,1461, 1376, 1248, 1053, 959, $970,838 \mathrm{~cm}^{-1}$. In the mass spectrum it showed a molecular ion peak at $\mathrm{m} / \mathrm{z} 467$. The ${ }^{1} \mathrm{H}$ NMR spectrum of the acylated derivative showed characteristic signals due to five tertiary methyl groups at $\delta_{\mathrm{H}} 0.68(3 \mathrm{H}, \mathrm{s}, \mathrm{C}-23), 0.69$ $(3 \mathrm{H}, \mathrm{s}, \mathrm{C}-24), 0.76(3 \mathrm{H}, \mathrm{s}, \mathrm{C}-25), 0.84(3 \mathrm{H}, \mathrm{s}, \mathrm{C}-26)$, $1.01(3 \mathrm{H}, \mathrm{s}, \mathrm{C}-27), 1.25$ (3H, s, C-28), and two secondary methyl signals as doublet centred at $0.79(3 \mathrm{H}$, $\mathrm{d}, \mathrm{J}=6.3 \mathrm{~Hz})$ and $0.92(3 \mathrm{H}, \mathrm{d}, \mathrm{J}=6.3 \mathrm{~Hz})$. The acetate methyl appeared as a singlet centred at $2.33(3 \mathrm{H}, \mathrm{s})$.

\subsection{Bioassay}

Suitable fungal strains were procured from the microbiology laboratory of our institute. DMSO (dimethyl sulphoxide) was used as solvent to prepare different concentrations of the triterpenoid. Solvent control (DMSO) was also maintained throughout the experiment. All experiments were performed in petridishes and were incubated at $37{ }^{\circ} \mathrm{C}$ for $48 \mathrm{~h}$. Culture media for fungal pathogens were prepared by mixing in suitable proportions of potato extract, dextrose and agar powder. All glass apparatus, culture media were autoclaved before use. The whole process was carried out in inoculation chamber.

\section{Results and discussion}

During our search towards bioactive natural products in tropical plants, ${ }^{10}$ we have investigated the chemical constituents of the $\mathrm{MeOH}$ extract of roots of $C$. bonplandianum, which showed potent antifungal activity against a series of fungal and bacterial pathogens. The investigation yielded the isolation of a new triterpene $3 \alpha$-hydroxy-urs-12,15-dien (1), along with two known triterpenoid oleanolic acid (2), ursolic acid (3) and most abundant $\beta$-sitosterol (4). All the compounds (1, 2 and 3) have been screened for their antimicrobial activity.

The $\mathrm{MeOH}$ extract of the roots of $C$. bonplandianum was suspended in water, partitioned successively between hexane, EtOAc and $n-\mathrm{BuOH}$ to get four fractions (hexane phase, ethylacetate phase, $n$-butanol phase and water phase). Since results of preliminary screening with the EtOAc soluble fraction was found to be most active against the fungal strain used, it was purified (through repeated column chromatography over silica gel) to isolate the active ingredients viz. $3 \alpha$-hydroxy-urs-12,15-dien (1), along with two known triterpenoids, oleanolic acid (2) and ursolic acid (3) and most abundant $\beta$-sitosterol (4). The structures of all the compounds were elucidated on the basis of chemical and spectroscopic analysis and by comparison (for compounds 2,3 and $\mathbf{4}$ ) with the spectral data of already reported compounds.

The elucidation of the structure of the new compound was accomplished by extensive analysis of its spectral data. Compound $\mathbf{1}$ was obtained as a white powder of melting point (mp) $244-246{ }^{\circ} \mathrm{C},[\alpha]_{\mathrm{D}}+4.0$, UV inactive, showed strong absorption band at 3422 (-OH), 2850, 1461, 1376 (gem dimethyl), 1053, 970, $959,838 \mathrm{~cm}^{-1}$ in the IR spectrum indicative of the presence of hydroxyl, olefinic and gem dimethyl groups. ${ }^{13} \mathrm{C}$ NMR spectrum at ambient temperature displayed signals for thirty carbons which were distinguished as eight methyls, seven methylenes, nine methines (five aliphatic, one oxygenated and three olefinic) and six quaternary with the aid of DEPT experiment. The ${ }^{1} \mathrm{H}$ NMR spectra of compound 1 (table 1) showed characteristic proton signals due to six tertiary methyl groups at $\delta_{\mathrm{H}}$ (proton chemical shift) $0.68\left(3 \mathrm{H}, \mathrm{s}, \mathrm{C}_{23}-\mathrm{Me}\right), 0.69$ $\left(3 \mathrm{H}, \mathrm{s}, \mathrm{C}_{24}-\mathrm{Me}\right), 0.76\left(3 \mathrm{H}, \mathrm{s}, \mathrm{C}_{25}-\mathrm{Me}\right), 0.84(3 \mathrm{H}, \mathrm{s}$, $\left.\mathrm{C}_{26}-\mathrm{Me}\right), 1.01\left(3 \mathrm{H}, \mathrm{s}, \mathrm{C}_{27}-\mathrm{Me}\right), 1.25$ ( $\left.3 \mathrm{H}, \mathrm{s}, \mathrm{C}_{28}-\mathrm{Me}\right)$, and two secondary methyl signals as doublet centred at $0.79\left(3 \mathrm{H}, \mathrm{d}, \mathrm{J}=6.3 \mathrm{~Hz}, \mathrm{C}_{29}-\mathrm{Me}\right)$ and $0.92(3 \mathrm{H}$, $\left.\mathrm{d}, \mathrm{J}=6.3 \mathrm{~Hz}, \mathrm{C}_{30}-\mathrm{Me}\right)$. The assignment of the signals of the methyl groups and the remaining ${ }^{1} \mathrm{H}$ and ${ }^{13} \mathrm{C}$ signals were performed through analysis of the HSQC, HMBC and COSY experiments and the results were found consistent with pentacyclic triterpene skeleton and its molecular formula was suggested to be $\mathrm{C}_{30} \mathrm{H}_{48} \mathrm{O}$ on the basis of ESIMS and TOFMS data $[\mathrm{m} / \mathrm{z}=424$ $\left(\mathrm{M}^{+}\right)$]. On acetylation it gave crystalline acetate of $\mathrm{mp}$ 223-224 ${ }^{\circ} \mathrm{C}$. The molecular formula of this acetate was suggested to be $\mathrm{C}_{32} \mathrm{H}_{50} \mathrm{O}_{2}$ [ESIMS data $\mathrm{m} / \mathrm{z}=$ $467(\mathrm{M}+1)]$. The difference in mass spectral data of 1 and its acetate indicated the formation of a monoacetate and hence indicated the presence of only one hydroxyl group in compound 1. IR spectrum of the monoacetate showed peaks at 2850, 1461, 1376 (gem dimethyl), 1248 (-OCOMe), 1053, 959, 970, $838 \mathrm{~cm}^{-1}$. The appearance of a sharp peak at $1376 \mathrm{~cm}^{-1}$ in the IR spectra of compound $\mathbf{1}$ and its monoacetate revealed the presence of a gem dimethyl group in ring A of the pentacyclic triterpenoid skeleton and the concordance of $\delta_{\mathrm{H}}$ 
Table 1. $1 \mathrm{H}, 13 \mathrm{C}$ chemical shift of compound $\mathbf{1}$ and $13 \mathrm{C}$ chemical shifs of $\mathbf{1}^{\mathrm{a}}, \mathbf{2}$ and $\mathbf{3}$.

\begin{tabular}{|c|c|c|c|c|c|}
\hline \multirow[b]{2}{*}{$\mathrm{C}$} & \multicolumn{2}{|r|}{1} & \multirow{2}{*}{$\begin{array}{l}\mathbf{1}^{\mathrm{a}} \\
\delta \mathrm{C}\end{array}$} & \multirow{2}{*}{$\begin{array}{l}\mathbf{2}^{\mathrm{b}} \\
\delta \mathrm{C}\end{array}$} & \multirow{2}{*}{$\begin{array}{l}\mathbf{3}^{\mathrm{b}} \\
\delta \mathrm{C}\end{array}$} \\
\hline & $\delta \mathrm{C}$ & $\delta \mathrm{H}$ & & & \\
\hline 1 & 40.5 & $1.03(\mathrm{~m}), 1.59$ (br. s) & 40.5 & 39.0 & 39.2 \\
\hline 2 & 29.7 & $1.65(\mathrm{~m}), 1.94(\mathrm{~m})$ & 29.7 & 28.1 & 28.2 \\
\hline 3 & 71.8 & $3.50(\mathrm{~m})$ & 74.0 & 78.2 & 78.2 \\
\hline 4 & 33.9 & & 33.9 & 39.4 & 39.6 \\
\hline 5 & 56.8 & 0.86 (br. s) & 56.7 & 55.9 & 55.9 \\
\hline 6 & 18.7 & $1.39(\mathrm{~m}), 1.48(\mathrm{~m})$ & 18.7 & 18.8 & 18.8 \\
\hline 7 & 31.9 & $1.51(\mathrm{~m}), 1.82(\mathrm{~m})$ & 31.8 & 33.4 & 33.7 \\
\hline 8 & 39.7 & & 39.7 & 39.8 & 40.1 \\
\hline 9 & 50.2 & $1.55(\mathrm{~m})$ & 50.0 & 48.2 & 48.1 \\
\hline 10 & 36.5 & & 36.5 & 37.4 & 37.5 \\
\hline 11 & 24.3 & $1.84(\mathrm{~m}), 1.98(\mathrm{~m})$ & 24.3 & 23.8 & 23.7 \\
\hline 12 & 121.7 & $5.33(\mathrm{~s}, \mathrm{t}-$ like $)$ & 122.6 & 122.6 & 125.7 \\
\hline 13 & 140.7 & & 139.6 & 144.8 & 139.3 \\
\hline 14 & 42.3 & & 42.3 & 42.2 & 42.6 \\
\hline $15^{*}$ & 129.2 & & 129.2 & 28.4 & 28.8 \\
\hline $16^{*}$ & 138.3 & & 138.3 & 23.8 & 25.0 \\
\hline 17 & 45.8 & & 45.8 & 46.7 & 48.1 \\
\hline 18 & 55.9 & $2.26(\mathrm{~d}, \mathrm{~J}=4.3 \mathrm{~Hz})$ & 55.9 & 42.1 & 53.6 \\
\hline 19 & 56.0 & $2.21(\mathrm{~m})$ & 56.0 & 46.6 & 39.5 \\
\hline 20 & 56.7 & 1.43 (br. s) & 56.6 & 31.0 & 39.4 \\
\hline 21 & 31.6 & $1.52(\mathrm{~d} \mathrm{~J}=5.6 \mathrm{~Hz}), 2.26(\mathrm{~d}, \mathrm{~J}=5.6 \mathrm{~Hz})$ & 31.8 & 34.3 & 31.1 \\
\hline 22 & 37.2 & $2.01($ br. s), 2.21 (br. s) & 36.9 & 33.2 & 37.4 \\
\hline 23 & 21.1 & $0.68(\mathrm{~s})$ & 21.1 & 28.8 & 28.8 \\
\hline 24 & 29.1 & $0.69(\mathrm{~s})$ & 29.1 & 16.5 & 16.5 \\
\hline 25 & 28.2 & $0.76(\mathrm{~s})$ & 28.2 & 15.6 & 15.7 \\
\hline 26 & 19.8 & $0.84(\mathrm{~s})$ & 19.8 & 17.5 & 17.5 \\
\hline 27 & 26.0 & $1.01(\mathrm{~s})$ & 26.0 & 26.2 & 24.0 \\
\hline 28 & 19.4 & $1.25(\mathrm{~s})$ & 19.3 & 180.0 & 179.7 \\
\hline 29 & 19.0 & $0.79(\mathrm{~d}, \mathrm{~J}=6.3 \mathrm{~Hz})$ & 19.0 & 33.4 & 17.5 \\
\hline 30 & 23.0 & $0.92(\mathrm{~d}, \mathrm{~J}=6.3 \mathrm{~Hz})$ & 23.0 & 23.8 & 21.4 \\
\hline
\end{tabular}

${ }^{\text {a }}$ Denotes acetyl derivative of compound 1; ${ }^{\mathrm{b}}$ measured in pyridine $d_{5}{ }^{*}$ Olefinic hydrogens attached to these carbons appeared as an $\mathrm{AB}$ q centred at $5.11 \mathrm{ppm}$ with $\mathrm{J}=15.1$ and $8.5 \mathrm{~Hz}$.

values in the ${ }^{1} \mathrm{H}$ NMR spectrum for the ring A with that of olean or ursane skeleton clearly rejected the possibility of the presence of friedelan skeleton. Mass fragmentation of the compound also followed the same pattern as was observed for typical pentacyclic triterenoids. ${ }^{11}$ A possible mass fragmentation pattern is depicted in scheme 1.

The comparison of the chemical shift positions $\left(\delta_{\mathrm{H}}\right)$ of the $\mathrm{A}, \mathrm{B}$ and $\mathrm{C}$ rings of $\mathbf{1}$, especially the resonances of the methyl groups and two secondary methyl signals on ring $\mathrm{E}$ provides the most useful indicator for the presence of ursane-type triterpenoid skeleton. ${ }^{12} \mathrm{~A}$ hydroxy methine signal at $\delta_{\mathrm{H}} 3.5(1 \mathrm{H}, \mathrm{m}, \mathrm{H}-3)$ and a trisubstituted olefinic signal at $\delta_{\mathrm{H}} 5.33(1 \mathrm{H}, \mathrm{d}, \mathrm{J}=$ $2.7 \mathrm{~Hz}, \mathrm{H}-12)$. However, the splitting nature and small $\mathrm{J}$ value may be considered by the consideration of long range coupling involving $\mathrm{H}-12$ and $\mathrm{H}-19$, both are closer in space. The through space distance is obviously more important than the number of intervening bonds, suggesting that $\mathbf{1}$ is a 3-hydroxy-urs-1,2-en type triterpenoid without possessing angular carboxyl group at C-28. ${ }^{10}$ Additionally, 1 showed an AB quartet $(>\mathrm{CH}=\mathrm{CH}<)$ centred at $\delta_{\mathrm{H}} 5.11(2 \mathrm{H}, J=15.1 \mathrm{~Hz}$ and $8.5 \mathrm{~Hz}, \mathrm{H}-15$ and $\mathrm{H}-16$ ) signifying the presence of another olefinic double bond having two olefinic protons that must be attributed to the vinylic protons of a disubstituted double bond in a six membered ring. ${ }^{13,16}$

${ }^{13} \mathrm{C}$ NMR spectrum showed all the 30 carbons and thereby confirmed the presence of a triterpene skeleton (table 1). Four downfield signals at $\delta_{\mathrm{C}} 121.7$ (C-12), 140.7 (C-13), 129.2 (C-15) and 138.3 (C-16) indicated the presence of four $\mathrm{sp}^{2}$ hybridized carbons. The signals at $\delta_{\mathrm{C}} 121.7$ and 140.7 are characteristic for a C-12/ C-13 double bond in the ursane type structure. ${ }^{13}$ The 
signal at $\delta_{\mathrm{C}} 140.7$ is due to the presence of a trisubstituted olefinic carbon at C-13 and peaks at $\delta_{\mathrm{C}} 138.3$ and 129.2 were indicative of the presence of another double bond having two disubstituted olefinic carbon. The ${ }^{13} \mathrm{C}$ values for these two carbons $\left(\delta_{\mathrm{C}} 138.3\right.$ and 129.2) clearly removed the possibility of any trisubstituted double bond. C-3 carbon appeared at $\delta_{\mathrm{C}} 71.8$ whereas for compounds $\mathbf{2}$ and $\mathbf{3}$ it appeared at $\delta_{\mathrm{C}} 78.2$, i.e., a shielding of seven units that signifying a stereochemical change at C-3. Therefore, for compound $\mathbf{1}$ the hydroxyl group is alpha instead of beta, i.e., it is an 3epi-urs-1,2-en type triterpenoid. On the other hand, the chemical shift of C-18 $\left(\delta_{\mathrm{C}} 55.9\right)$ in compound 1 was very close to that in compound $\mathbf{3}\left(\delta_{\mathrm{C}} 53.6\right)$, which indicated that these two compounds have the same configuration at C-18. Eight methyl signals appeared at $\delta_{\mathrm{C}} 21.1$

Table 2. $1 \mathrm{H}-13 \mathrm{C}$ long range correlation detected in the $\mathrm{HMBC}$ spectra of compound 1 ( $\delta$ relative to TMS in $\mathrm{CDCl}_{3}$ ).

\begin{tabular}{lc}
\hline Proton & Correlated C \\
\hline $1.01(\mathrm{H}-27)$ & $39.7(\mathrm{C}-8), 140.7(\mathrm{C}-13), 42.3(\mathrm{C}-14)$, \\
& $129.2(\mathrm{C}-15), 50.1(\mathrm{C}-9), 128.3(\mathrm{C}-16)$ \\
$0.84(\mathrm{H}-26)$ & $39.7(\mathrm{C}-8), 42.3(\mathrm{C}-14)$ \\
$1.25(\mathrm{H}-28)$ & $45.8(\mathrm{C}-17)$ \\
$0.68(\mathrm{H}-23)$ & $33.9(\mathrm{C}-4), 56.8(\mathrm{C}-5), 71.8(\mathrm{C}-3)$ \\
$1.55(\mathrm{H}-9)$ & $36.5(\mathrm{C}-10), 39.7(\mathrm{C}-8)$, \\
& $19.8(\mathrm{C}-26), 28.2(\mathrm{C}-25)$ \\
$5.33(\mathrm{H}-12)$ & $50.1(\mathrm{C}-9), 42.3(\mathrm{C}-14), 55.9(\mathrm{C}-18)$ \\
$2.26(\mathrm{H}-18)$ & $121.7(\mathrm{C}-12), 140.7(\mathrm{C}-13)$, \\
& $42.3(\mathrm{C}-14), 128.3(\mathrm{C}-16)$, \\
& $45.8(\mathrm{C}-17), 56.0(\mathrm{C}-19)$, \\
& $56.7(\mathrm{C}-20), 19.4(\mathrm{C}-28)$ \\
\hline
\end{tabular}

(C-23), 29.1 (C-24), 18.7 (C-25), 19.8 (C-26), 24.3 (C27), 19.4 (C-28), 19.0 (C-29) and 23.0 (C-30). Assignments of all the carbons were made by comparison with that reported in literature for ursane skeleton ${ }^{14}$ and are tabulated in table 1.

The structure of compound $\mathbf{1}$ was finally established by 2D NMR experiments. The methyl singlet at $\delta_{\mathrm{H}} 1.25$ was correlated with a carbon signal at $\delta_{\mathrm{C}} 19.4$ in the HMQC spectrum were assigned to $\mathrm{H}_{3}-28$ from $\mathrm{HMBC}$ correlation observed from $\mathrm{H}_{3}-28\left(\delta_{\mathrm{H}} 1.25\right)$ to $\mathrm{C}-17\left(\delta_{\mathrm{C}}\right.$ 45.8). Another methyl singlet at $\delta_{\mathrm{H}} 0.84\left(3 \mathrm{H}, \mathrm{s}, \mathrm{C}_{26^{-}}\right.$ $\mathrm{Me}$ ), was correlated with carbon singlet at $\delta_{\mathrm{C}} 19.8$ in the HMQC spectrum, were assigned to $\mathrm{H}_{3}-26$ from the HMBC correlation observed from $\mathrm{H}_{3}-26\left(\delta_{\mathrm{H}} 0.84\right)$ to C-8 $\left(\delta_{\mathrm{C}} 39.7\right)$. The presence of a trisubstituted olefin between $\mathrm{C}-12$ and $\mathrm{C}-13$ was revealed by the $\mathrm{HMBC}$ correlations observed for $\mathrm{H}_{2}-11 / \mathrm{C}-12, \mathrm{H}_{2}-11 / \mathrm{C}-13, \mathrm{H}-$ 18/C-13 and $\mathrm{H}_{3}-27 / \mathrm{C}-13$. Finally, 2D NMR techniques were applied to locate the exact position of another double bond. Both the COSY and HMBC spectra gave significant information regarding the position of the double bond between $\mathrm{C}-15$ and $\mathrm{C}-16$. The COSY spectrum revealed two significant correlations of $\mathrm{H}-18$ at $\delta_{\mathrm{H}} 2.26$ $(1 \mathrm{H}, \mathrm{d}, \mathrm{J}=4.3 \mathrm{~Hz})$ with a proton at $\delta_{\mathrm{H}} 5.13(1 \mathrm{H}, \mathrm{AB}$ $\mathrm{q}, \mathrm{J}=15.1$ and $8.5 \mathrm{~Hz})$ and a proton at $\delta_{\mathrm{H}} 5.01(1 \mathrm{H}$, $\mathrm{AB} \mathrm{q}, \mathrm{J}=15.1$ and $8.5 \mathrm{~Hz}$ ). In the HMBC spectrum (table 2) cross peaks were observed due to $\mathrm{H}_{3}-27$ at $\delta_{\mathrm{H}}$ $1.01(\mathrm{~s}, 3 \mathrm{H}) / \delta_{\mathrm{C}} 129.2$ and $\mathrm{H}_{3}-28$ at $\delta_{\mathrm{H}} 1.25(\mathrm{~s}, 3 \mathrm{H}) / \delta_{\mathrm{C}}$ 138.3. Two olefinic protons at $\delta_{\mathrm{H}} 5.13(1 \mathrm{H}, \mathrm{AB} \mathrm{q}, \mathrm{J}=$ $15.1,8.5 \mathrm{~Hz})$ and $\delta_{\mathrm{H}} 5.01(1 \mathrm{H}, \mathrm{q}, \mathrm{J}=15.1,8.5 \mathrm{~Hz})$ in effect showed correlations in COSY spectrum. From the above data it was confirmed that compound $\mathbf{1}$ has a second double bond between $\mathrm{C}_{15}$ and $\mathrm{C}_{16}$. The appearance

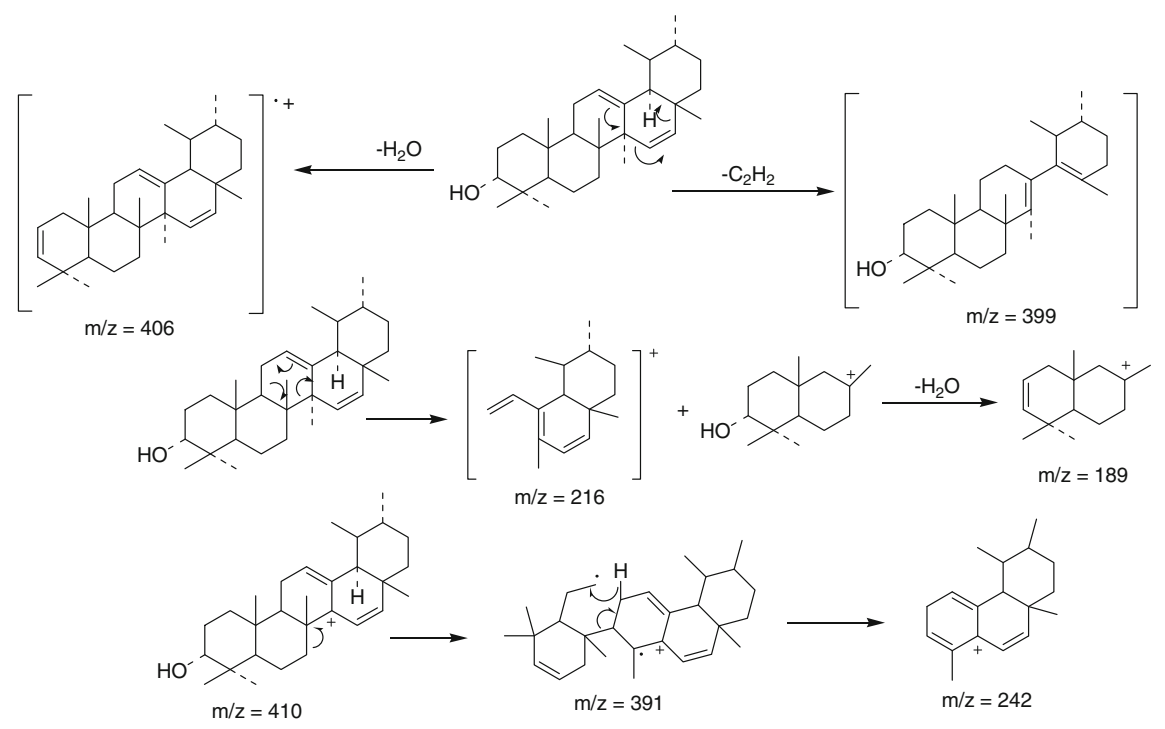

Scheme 1. Proposed mass fragmentation pattern of compound $\mathbf{1 .}$ 


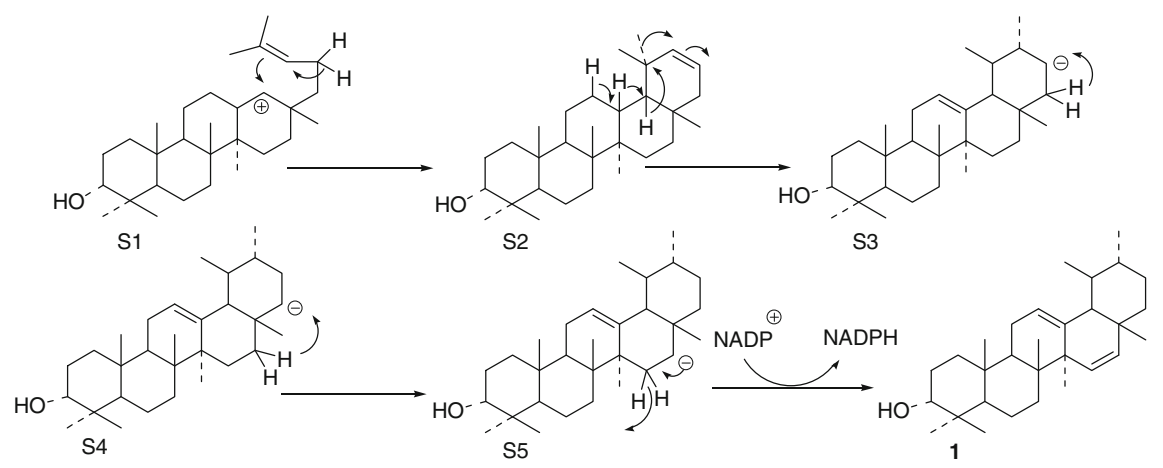

Scheme 2. Probable biosynthetic pathway of compound $\mathbf{1}$

of such an $\mathrm{AB}$ quartet for such type of double bond in ring $D$ of pentacyclic triterpenoid, between $C_{15}$ and $C_{16}$, was reported in literature. ${ }^{15,16}$ Thus on the basis of the above data the structure of compound $\mathbf{1}$ was established as $3 \alpha$-hydroxy-urs-12,15-diene.

Spectral analysis (IR, NMR, Mass, etc.) of the prepared acetate derivative provide further evidence in favour of the proposed structure of compound 1 ( $3 \alpha-$ hydroxy-urs-12,15-diene). Mass spectrum showed the incorporation of only one acetyl group (at $\mathrm{m} / \mathrm{z} 467$ ) and thus confirming the presence of only one hydroxyl group. IR spectrum of the monoacetate showed peak at $1248 \mathrm{~cm}^{-1}$ in addition to other peaks for the acetate group. In the ${ }^{1} \mathrm{H}$ NMR spectrum acetate methyl appeared as a singlet centred at $\delta_{\mathrm{H}} 2.33(3 \mathrm{H}, \mathrm{s})$ and the $\mathrm{C}_{3}-\mathrm{H}$ shifted downfield $\left(\delta_{\mathrm{H}} 4.61, \mathrm{~m}, 1 \mathrm{H}\right)$ in comparison to the same $\left(\delta_{\mathrm{H}} 3.52, \mathrm{~m}, 1 \mathrm{H}\right)$ for the hydroxyl methine part in compound 1 . The ${ }^{13} \mathrm{C}$ spectrum showed all the carbons for the monoacetate derivative. C-3 appeared at $\delta_{\mathrm{C}} 74.0$ (shifted downfield with respect to that of the original compound, 1) and the acetate carbonyl signal appeared at $\delta_{\mathrm{C}} 170.5$. The DEPT and COSY spectra of the acetylated derivative were in good agreement to that proposed for the acetylated derivative (5) and thus established the structure of compound $\mathbf{1}$ as $3 \alpha$-hydroxy-urs-12,15-dien.

Purification of compound 2 yielded a white powder of mp 306-308 ${ }^{\circ} \mathrm{C}$ and its molecular formula was

Table 3. MIC of compound $\mathbf{1}$ against different fungi.

\begin{tabular}{lccccc}
\hline & \multicolumn{5}{c}{ MIC of $\mathbf{1}$ in $\mu \mathrm{g} / \mathrm{mL}$ against different fungi } \\
\cline { 2 - 6 } Compound & CC & CG & AA & FE & CE \\
\hline 1 & 10 & $<15$ & 10 & $<10$ & 15 \\
2 & $<10$ & 20 & 10 & $<10$ & 10 \\
3 & 15 & $<10$ & 10 & $<15$ & $<15$ \\
Bavistin & 2.5 & 1.25 & 2.5 & 2.5 & $<2.5$ \\
\hline
\end{tabular}

suggested to be $\mathrm{C}_{30} \mathrm{H}_{50} \mathrm{O}_{3}$ on the basis of FAB MS data $\left[\mathrm{m} / \mathrm{z}=458.2(\mathrm{M})^{+}\right]$and its structure was elucidated as oleanolic acid by ${ }^{1} \mathrm{H}$ and ${ }^{13} \mathrm{C}$ NMR data and that already reported in literature. ${ }^{17}$

Compound $\mathbf{3}$ was also obtained as a white powder of mp $280-282{ }^{\circ} \mathrm{C}$. Its molecular formula was suggested to be $\mathrm{C}_{30} \mathrm{H}_{50} \mathrm{O}_{3}$ on the basis of FAB MS data $[\mathrm{m} / \mathrm{z}=$ $458.5(\mathrm{M})^{+}$and was finally identified as ursolic acid by ${ }^{1} \mathrm{H}$ and ${ }^{13} \mathrm{C}$ NMR data and that already reported in literature. ${ }^{17}$

Purification of the most polar fraction (8\% ethyl acetate in petroleum ether) afforded white crystals of mp $136-137{ }^{\circ} \mathrm{C}, \mathrm{M}^{+} 414$, and was identified as $\beta$ sitosterol 4 by spectral analysis and by comparison with an authentic sample of $\beta$-sitosterol (mixed mp, co-IR, and co-tlc, etc.).

A probable biosynthetic pathway for the formation of the new triterpenoid $\mathbf{1}$ has depicted in scheme 2 on the basis of the formation of $\alpha$-amyrin. ${ }^{18}$ This is followed by the formation of a transient carbanion intermediate (S3) and its subsequent rearrangement to S5. Catalytic role of $\mathrm{NADP}^{+}$present in cells/tissue was then suggested for the formation of $\mathbf{1}$.

All the compounds $(\mathbf{1}, \mathbf{2}$ and $\mathbf{3})$ isolated from the ethyl acetate soluble fraction were tested for their antifungal activity by the disc diffusion method (table 3) against the microorganisms which are very much native to North Bengal, ${ }^{19}$ India; viz. Calletotricheme camellie, Fussarium equisitae, Alterneria alternate, Curvularia eragrostidies and Colletrichum gleosproides. These fungal pathogens are responsible to cause wilt disease to tomatoes, pineapple, etc. cultivated traditionally in this region. The MIC values including that of reference sample Bavistin are tabulated in table 3. The MIC values of Bavistin against these fungal pathogens were also determined. A comparison of antifungal activities of compound 1, 2 and $\mathbf{3}$ to that of Bavistin showed that although they are less active compare to Bavistin, but 
all of them exhibited moderately good activity against all the fungal pathogens tested.

\section{Conclusion}

A new triterpenoid of ursane skeleton has been isolated from the root of $C$. bonplandianum and characterized as $3 \alpha$-hydroxy-urs-12,15-dien (1) along with two known triterpinic acids, oleanolic acid (2) and ursolic acid (3). $\beta$-sitosterol (4) was also obtained as the most polar fraction of the ethylacetate phase. Antifungal potentiality of compound 1 was also detected against five different fungal pathogens. A plausible biosynthetic pathway was also suggested.

\section{Supplementary information}

The electronic supporting information can be seen in www.ias.ac.in/chemsci.

\section{Acknowledgement}

Financial support from the University Grants Commission (UGC), New Delhi, India is acknowledged.

\section{References}

1. Kaul V 1967 J Indian Bot. Soc. 46154

2. Bhakat R K and Sen U K 2008 Tribes Tribals 255
3. Chaudhuri A B 2007 Endangered medicinal plants (Delhi: Daya Publishing House)

4. Nishanta R, Harris C S and Towers G H N 2002 Pharmaceut. Biol. 40235

5. Maria C M T, João C A, Gilvandete M P S, Manoel A N, Edilberto R S, Leticia V C L, Daniel P B D, José B M F, Francisco A V and Otília P D L 2008 J. Chem. and Biodiver. 52724

6. Jeeshna M V, Mallikadevi T and Paulsamy S 2010 J. Biopesticides 3(1 Special Issue) 192

7. Rizk A F M 1987 Bot. J. Linn. Soc. 94293

8. Phillipson J D 1995 Phytochemistry 381319

9. Islam M S, Rahman M M, Rahman M A, Qayum M A and Alam M F 2010 J. Agric. Technol. 679

10. Ghosh P, Mandal A, Rasul M G, Chakraborty M and Saha A 2010 Indian J. Pharm. Sci. 72504

11. Budzikiewicz H, Wilson J M and Djerassi C $1963 \mathrm{~J}$. Am. Chem. Soc. $\mathbf{8 5} 3688$

12. Johns S R, Lamberton J A, Morton T C, Suares H and Willing R I 1983 Aust. J. Chem. 362537

13. Durham D G, Liu X and Richards R M E 1994 Phytochemistry 361469

14. Weis R and Seebacher W 2003 Magn. Reson. Chem. 40 455

15. Saha B, Naskar D B, Mishra D R and Khastagir H N 1977 Tetrahedron Lett. 353095

16. Thomson J 1966 Tetrahedron 22351

17. Seebacher W, Simic N, Weis R, Saf R and Kunert O 2003 Magn. Reson. Chem. 41636

18. Rees H H, Mercer E I and Goodwin T W 1966 Biochem. J. 99726

19. Ghosh P, Mandal A and Chakraborty M $2010 \mathrm{~J}$. Chem. Pharm. Res. 2714 